\title{
Uji Mekanik Membran Kitosan Berbahan Dasar Cangkang Kepiting
}

\author{
Indah Lestari ${ }^{\left.{ }^{*}\right)}$, Dwi Sabda Budi Prasetya ${ }^{2)}$, Dwi Pangga ${ }^{3)}$ \\ ${ }^{1,2 \notin 3)}$ Program Studi Pendidikan Fisika, FPMIPA, IKIP Mataram \\ *Email:taricitari97@gmail.com
}

Article History

Received: April 2018

Reviewed: May 2018

Published: June 2018

Key Words

Chitosan;

Crab shell;

PVA (Poly Vinly Acetat);

Membrane

\section{Sejarah Artikel}

Diterima: April 2018

Direviu: Mei 2018

Dipublikasi: Juni 2018

Kata Kunci:

Kitosan;

Cangkang kepiting;

PVA (Poly Vinly Acetat);

Membran

How to cite this article?

\begin{abstract}
[Title: The Effect of Thinking Aloud Pair Problem Solving Learning Model Toward Student Physics Science Learning Outcomes]. This study aims to test mechanical on membrane composite membrane based crab shell and poly vinly Acetat (PVA). A mechanical test was performed to test the young modulus of the membrane in maintaining pore size using the "Tensilon" machine. The results show that chitosan / Poly Vinly Acetate composite membrane with preparation of comparison $25 \%-75 \%, 50 \%-50 \%$ and $75 \%-25 \%$. For sample 25\% -75\% experience drying process faster than other sample. On the mechanical test of chitosan membrane I Poly Vinly Acetat showed the biggest value that is equal to $9.84 \mathrm{Mpa}$ on comparison preparation $50 \%-50 \% .25 \%-75 \%$ and $75 \%-25 \%$ preparations decreased by $4.68 \mathrm{MPa}$ and $1.37 \mathrm{Mpa}$.
\end{abstract}

\begin{abstract}
Abstrak
Penelitian ini bertujuan untuk uji mekanik pada membran komposit kitosan berbahan dasar cangkang kepiting dan poly vinly Acetat (PVA). Uji mekanik dilakukan untuk menguji modulus young pada membran dalam mempertahankan ukuran pori menggunakan mesin "Tensilon". Hasil menunjukan bahwa membran komposit kitosan/Poly Vinly Acetat dengan preparasi perbandingan $25 \%-75 \%, 50 \%-50 \%$ dan $75 \%-25 \%$. Untuk sampel 25\%-75\% mengalami proses pengeringan lebih cepat dari pada sampel yang lainnya. Pada uji mekanik membran kitosan/Poly Vinly Acetat menunjukan nilai terbesar yaitu sebesar 9.84 Mpa pada preparasi perbandingan $50 \%-50 \%$. preparasi $25 \%-75 \%$ dan $75 \%-25 \%$ mengalami penurunan sebesar $4.68 \mathrm{Mpa}$ dan $1.37 \mathrm{Mpa}$. kesimpulannya membuktikan bahwa membran yang memiliki komposisi sama antara kitosan dengan Poly Vinly Acetat menyebabkan ukuran pori yang rapat, teratur, dan saling berdekatan. Proses pengeringan yang cepat menyebabkan membran menjadi kuat.
\end{abstract}

Lestari, I., Prasetya, D., S., B., \& Pangga, D. (2018). Uji Mekanik Membran Kitosan Berbahan Dasar Cangkang Kepiting. Lensa: Jurnal Kependidikan Fisika, 6(1), 23-28.

\section{PENDAHULUAN}

Indonesia memiliki limbah cangkang kepiting dari tahun ke tahun mengalami peningkatan, terbukti dari data BPS (PPLD-LIPI, 2015), total produksi udang dan kepiting dari Indonesia rata-rata mencapai setidaknya 160.000 ton/tahun. Dengan asumsi bahwa $25 \%$ dari berat tersebut adalah cangkangnya, maka limbahnya dapat mencapai setidaknya 40.000 ton/tahun. Cangkang kepiting merupakan limbah yang mudah didapat dan tersedia dalam jumlah yang sangat banyak, selama ini belum termanfaatkan secara optimal. Cangkang kepiting merupakan senyawa kimia yang mengandung kitosan dan presentase kitin terbesar yaitu sebesar $71 \%$. Kitosan merupakan suatu polimer yang bersifat polikatiolik. Kitosan termkasud polimer alamiah yang dapat ditemukan di alam berbeda-beda tergantung pada sumbernya. polimer mengakibatkan kitosan sangat efektif mengadsorpsi kation ion logam berat maupun kation dari zat-zat organik (protein dan lemak).

Dewasa ini sebagian kecil dari limbah kepiting memang sudah dimanfaatkan, akan tetapi, masih banyak limbah yang beresakan sehingga mengganggu lingkungan. Pembuatan membran 
kitosan berbahan dasar cangkang kepiting dikompositkan dengan PVA adalah solusi yang tepat karena diakui lebih efektif oleh para peneliti sebelumnya. Membran adalah salah satu jenis material yang masih serupa dengan karet sintesis. Salah satu penelitian dilakukan oleh Indah F. Fahra, dkk (2012), dalam pengaplikasian kitosan dilakukan dengan teknologi membran, karena mempunyai berbagai keunggulan dibandingkan metode lain, di antaranya proses dapat dilakukan secara kontinyu, tidak memerlukan zat kimia tambahan, konsumsi energi rendah, dapat dilangsungkan pada temperatur rendah sehingga dapat digunakan untuk pemisahan senyawa yang tidak tahan temperatur tinggi, mudah dalam pengaturannya, serta tidak membutuhkan kondisi yang ekstrim.

Membran yang terbentuk dari komposit kitosan berbahan dasar cangkang kepiting-PVA (Poly Vinyl AcetatI) akan dilakukan uji mekanik untuk mengetahui kuat putus dan modulus young. Uji kuat putus merupakan salah satu pengujian untuk mengetahui sifat-sifat suatu bahan. Dengan menarik suatu bahan kita akan segera mengetahui bagaimana bahan tersebut bereaksi terhadap tenaga tarikan dan mengetahui sejauh mana material itu bertambah panjang. Sedangkan modulus young adalah angka yang digunakan untuk mengukur objek atau ketahanan bahan untuk mengalami deformasi elastis ketika gaya diterapkan pada benda tersebut.

\section{METODE PENELITIAN}

Alat Penelitian : pengaduk magnetik, alat uji teknik mekanik meliputi kuat putus dan modulus young.

Bahan Penelitian : PVA (polivinly Acetat), Aquades, Asam Asetat 1\%, dan kitosan dari cangkang kepiting.

\section{Langkah-langkah Penelitian}

a. Pembuatan membran komposit kitosan dan PVA

1. kitosan sebanyak 1,5 gram dilarutkan kedalam $50 \mathrm{ml}$ asam asetat $1 \%(\mathrm{v} / \mathrm{v})$, dan diaduk dengan menggunakan pengaduk magnetik hingga homogen.

2. Selanjutnya PVA sebanyak 1,5 gram dilarukan kedalam $50 \mathrm{ml}$ Aquades yang diaduk menggunakan pengaduk magnetik hingga larutan homogen

3. Larutan dari kitosan dan PVA yang tebentuk kemudian di campurkan dengan perbandingan masing-masing sebesar75\%: $25 \%, 50 \%: 50 \%$, dan dan $25 \%: 75 \%$, diaduk dengan menggunakan pengaduk magetik hingga homogen

4. Campuran larutan yang telah homogen dituangkan ke dalam cetakan dan dikeringkan pada suhu kamar hingga diperoleh film kitosan-PVA kering.

5. Setalah film kitosan-PVA kering dipotong sesuai dengan SNI. Dapat dilihat dari Gambar 1.

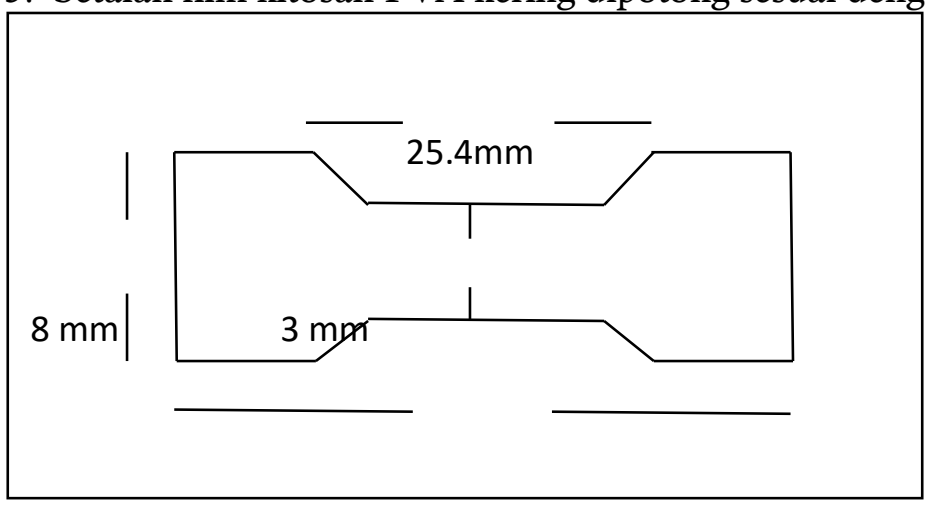

Gambar 1. Film kitosan-PVA kering dipotong sesuai dengan SNI

Teknik analisa data

a. Kuat putus, sesuai dengan persamaan :

Keterangan :

$$
\sigma=\frac{\mathrm{F}}{\mathrm{A}}
$$

$\sigma \quad=$ kuat putus $(\mathrm{MPa})$

$\mathrm{F} \quad=$ beban pada saat putus $(\mathrm{N})$ 
A $=$ luas penampang $\left(\mathrm{mm}^{2}\right)$

b. Perpanjangan saat putus, sesuai dengan persmaan :

Keterangan :

$$
\varepsilon=\frac{\Delta \mathrm{L}}{\mathrm{l}_{\mathrm{o}}}
$$

$\varepsilon \quad=$ perpanjangan saat putus

$\Delta \mathrm{L}=$ panjang pada saat putus $(\mathrm{mm})$

$1_{\mathrm{o}} \quad$ = panjang mula-mula $(\mathrm{mm})$

c. Modulus Young, sesuai dengan persmaan :

Keterangan :

$$
\mathrm{E}=\frac{\sigma}{\varepsilon}
$$

$\mathrm{E}=$ modulus young $(\mathrm{MPa})$

$\varepsilon \quad=$ perpanjangan saat putus

$\sigma \quad=$ kuat putus bahan $(\mathrm{MPa})$

\section{HASIL DAN PEMBEHASAN}

\section{Pembuatan Membran komposit kitosan-PVA}

Pada penelitian ini membran dibuat dengan teknik infersi fasa yang dilakukan dengan cara melarutkan 1,5 gram kitosan dalam $50 \mathrm{ml}$ asam asetat $1 \%$ yang diaduk kurang lebih 2 jam hingga larutan homogen dan melarutkan 1,5 gram PVA dalam $50 \mathrm{ml}$ aquades selama 2 jam dan 1 jam pertama disertai dengan pemanasan. Setelah larutan kitosan dan larutan PVA terbentuk maka kedua larutan tersebut dapat dicampurkan dengan perbandingan masing-masing 25\%:75\%, 50\%:50\% dan 75\%:25\% v/v. Larutan yang telah terbentuk dituang perlahan-lahan pada cetakan yang berbentuk persegi panjang. Kemudian cetakan tersebut dibiarkan menguapkan pelarutnya dalam waktu dua hari pada suhu kamar sehingga terbentuk pori-pori pada membran dan membran mengering.

Setelah proses pengeringan membran selesai, untuk melepaskan membran dari cetakan,

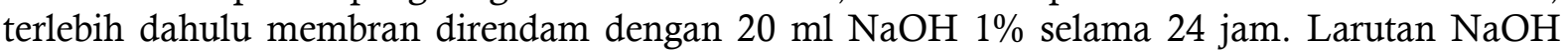
dalam hal ini berfungsi sebagai non pelarut yang dapat berdifusi ke bagian bawah membran yang menempel pada cetakan, sehingga membran dapat terangkat. Kemudian membran ditarik secara perlahan-lahan dan dicuci dengan aquades secara berulang-ulang untuk menghilangkan alkali yang masih menempel pada membran.

Membran kitosan-PVA dengan perbandingan 25\%:75\%, 50\%:50\% dan 75\%:25\% v/v dihasilkan berupa lembaran tipis, secara kasat mata terlihat memiliki permukaan yang rata dan memiliki perbedaan pada kedua permukaannya, permukaan atas yang lebih kasar dan permukaan bawah yang menempel pada cetakan memiliki permukaan yang lebih halus. Sedangkan pada membran dengan perbandingan 25\%:75\% dihasilkan membran yang berwarna putih bening dan memiliki struktur yang lebih cepat kering.

\section{Uji Mekanik Membran Kitosan-PVA}

Analisis sifat mekanik yang dilakukan untuk menunjukkan hasil analisis sifat mekanik berupa kuat putus, perpanjangan saat putus, dan modulus Young membran komposit kitosanPVA. Proses uji mekanik membran membutuhkan waktu kurang lebih 20 menit untuk meprsiapkan mesin dan sampel yang akan digunakan sedangkan durasi penarikan selama 10 detik per satu sampel. Hasil uji mekanik membran komposit kitosan-PVA menggunakan mesin Tansilon dengan perbandingan yang telah ditentukan dan dilakukan pengadukan selama 4 hari serta pengerigan dilakukan selama 2 hari diperlihatkan pada Tabel 1.

Tabel 1. Hasil uji mekanik membran komposit kitosan-PVA

\begin{tabular}{cccccc}
\hline Membran Kitosa-PVA & F (Mpa) & $\Delta \mathrm{L}(\mathrm{mm})$ & $\sigma(\mathrm{Mpa})$ & $\varepsilon$ & $\begin{array}{c}\mathrm{E} \\
(\mathrm{Mpa})\end{array}$ \\
\hline $25 \%-75 \%$ & 6,42 & 1,16 & 2,14 & 0,457 & 4,68 \\
\hline $50 \%-50 \%$ & 7,68 & 0,68 & 2,56 & 0,26 & 9,84 \\
\hline $75 \%-25 \%$ & 4,11 & 2,77 & 1,37 & 1,09 & 1,37 \\
\hline
\end{tabular}


Dengan :

$$
\begin{array}{ll}
\mathrm{F} & =\text { Beban }(\mathrm{Mpa}) \\
\Delta \mathrm{L} & =\text { Perubahan panjang }(\mathrm{m}) \\
\boldsymbol{\tau} & =\text { Kuat tarik (tegangan) }(\mathrm{Mpa}) \\
\boldsymbol{\varepsilon} & =\text { Regangan }(\%) \\
\mathbf{E} & =\text { Modulus young }(\mathrm{Mpa})
\end{array}
$$

Uji kekuatan tarik membran kitosan-PVA proses pemisahanya belangsung dengan suhu kamar, memilki sifat yang bervariasi, dan dapat digunakan dan diatur sesuai dengan kebutuhan. Kekuatan tarik membran dapat dilihat dari nilao load yaitu nilai kuat tegangan saat putus dan nilai steoke yaitu nilai renggangan pada saat membran putus.

Dari data tabel 4.1. dapat diketahui bahwa membran pada perbandingan $75 \%-25 \%$ memiliki nilai tegangan yang paling rendah yaitu $1.27 \mathrm{Mpa}$, hal ini disebabkan pada proses pengeringan membutuhkan waktu lama menyebabkan banyak rongga udara yang masih terperangkap pada membran sehingga membuat membran mudah putus. Kekuatan tarik pada saat putus (tegangan) mengalami peningkatan dengan berkurangnya konsentrasi kitosan yaitu pada perbandingan $25 \%-75 \%$, proses pengeringan membran lebih cepat akan tetapi pada perbandingan ini membran memiliki ukuran pori yang besar dari pada perbandingan yang lain sehingga menyebabkan membran lebih cepat rapuh. Hal ini terbukti dari kekuatan tarik yang kurang tinggi yaitu sebesar 2.1406 Mpa. Kekuatan tarik yang paling tinggi pada perbandingan $50 \%-50 \%$ yaitu $2.56 \mathrm{Mpa}$. Hal tersebut dikarenakan komposisi yang pas antaran kitosan-PVA. Proses pengeringan membran yang cepat dan ukuran pori serta jarak molekulnya yang lebih rapat menyebabkan membran memiliki kekuatan tarik yang tinggi. Dapat dilihat pada gambar 2 .

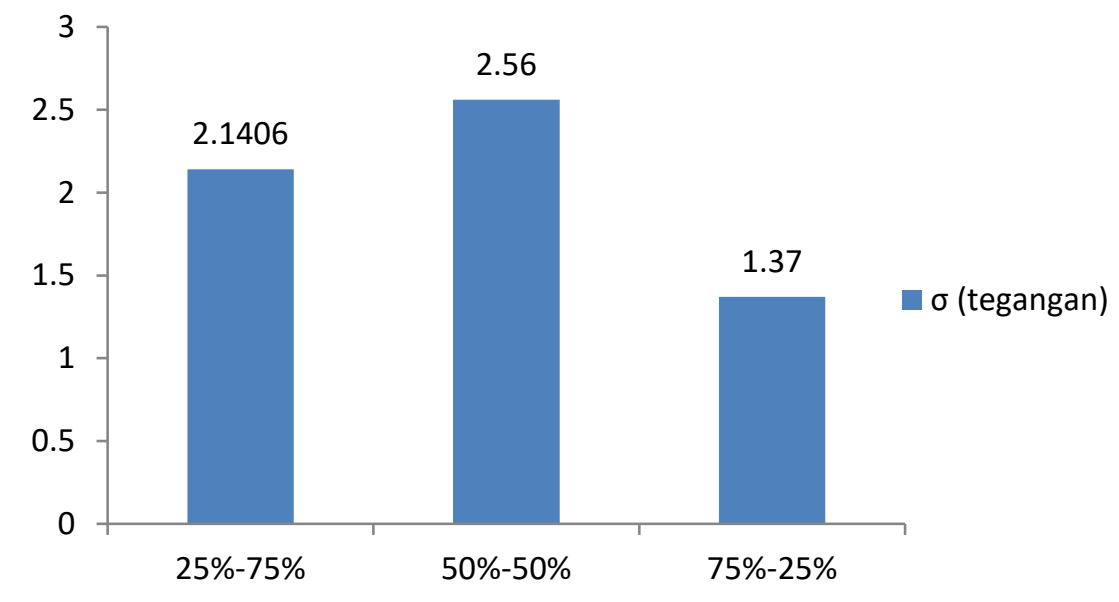

Gambar 2. Hasil perbandingan tegangan

Uji mekanik kekutan tarik berbeda dengan hasil regangan hal ini terbukti dari tabel 4.1. bahwa regangan yang paling tinggi pada perbandingan 75\%-25\% yaitu $1.09 \mathrm{Mpa}$. Penambahan kitosan pada membran mengakibatkan terjadinya ikatan hidrogen antara gugus OH dari PVAaquades dengan asam asetat-kitosan. Adanya ikatan hidrogen pada membran komposit kitosanPVA mengakibatkan mobilitas molekuler membran berkurang. Pengurangan mobilitas molekuler ini disebabkan semakin kecil kitosan maka akan meningkatkan perpanjangan saat putus dan menurunkan kuat tarik membran komposit kitosan-PVA. Hal ini diperkuat dengan Gambar 3. 


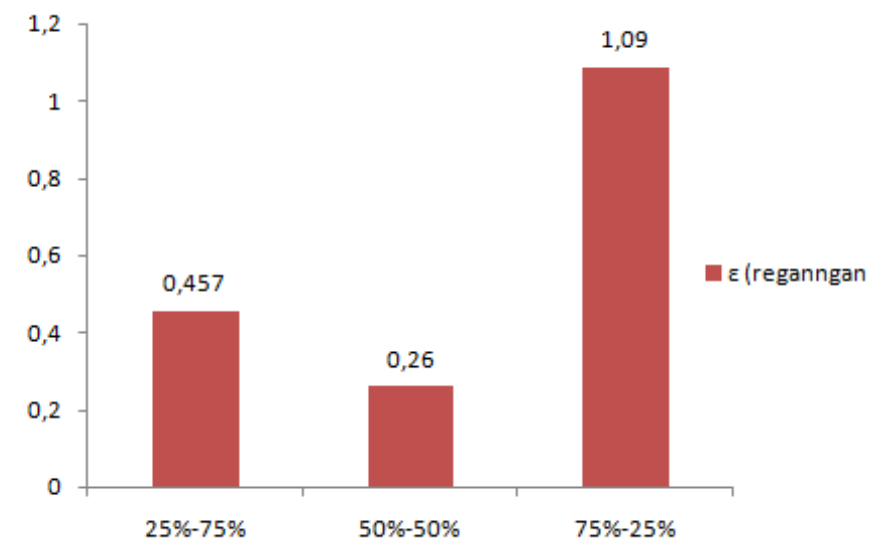

Gambar 3. Hasil perbandingan regangan

Penambahan kitosan dapat menurunkan perpanjangan saat putus (regangan) membaran komposit kitosan-PVA. Dengan demikian penambahan kitosan dapat mempengaruhi sifat mekanik membran. Adanya perbedaan hasil yang diperoleh dari perpanjangan saat putus membran membuktikan bahwa kurangnya ketelitian pada saat penelitian. Membran kitosan dengan perpanjangan saat putus tertinggi dapat dipilih dan diharapkan dapat diaplikasikan dalam bidang medis.

Dari semua data yang diperoleh kekuatan terendah pada komposisi 25\%-75\% dengan hasil 4.68 $\mathrm{MPa}$ dan 75\%-25\% modulus young sebesar $1.37 \mathrm{Mpa}$. Sedangkan kekuatan membran terbesar terdapat pada membran dengan perbandingan 50\%-50\%, hal tersebut dapat diketahui bahwa sedikit banyak kitosan dapat mempengaruhi membran terutama meningkatkan kuat putus (tidak signifikan) dan menurunkan perpanjangan saat putus dari membran serta dapat dilihat dari nilai modulus young yang sangat tinggi yaitu sebesar 9,84 $\mathrm{MPa}$. Hal tersebut dikarenakan pada membran ini memiliki komposisi yang sama atau pas antara kitosan dengan PVA sehingga membran memiliki ukuran pori yang rapat, teratur, dan saling berdekatan serta proses pengeringan yang cepat menyebabkan interaksi antara molekul yang sangat kuat dan membutuhkan energi yang cukup besar untuk memutuskan membran. Hal ini diperkuat dari gambar 4 .

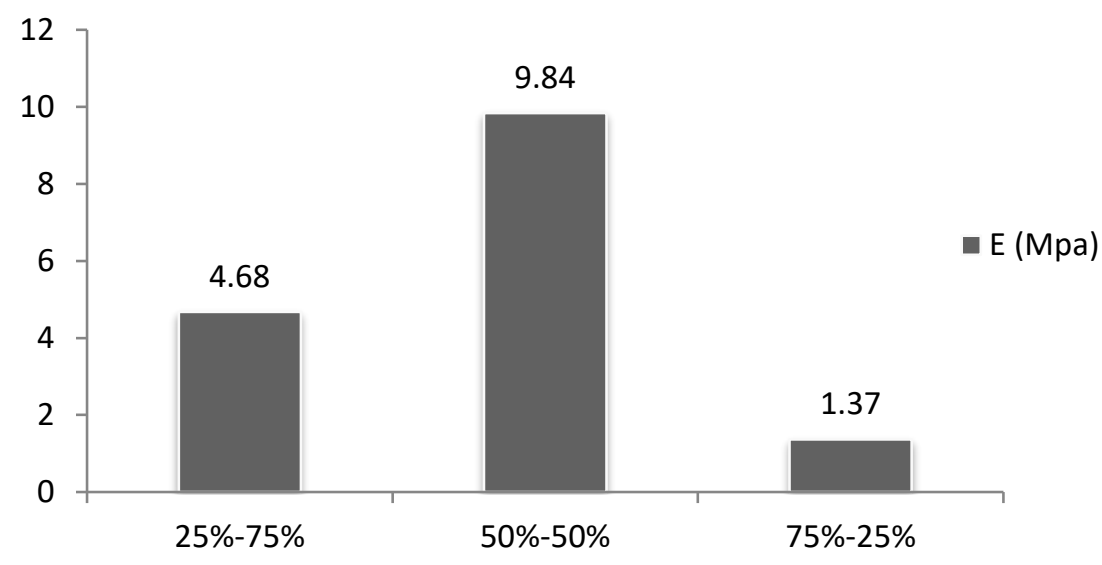

Gambar 4. Hasil perbandingan modulus young

\section{KESIMPULAN}

1. Kekuatan tarik yang paling tinggi pada perbandingan 50\%-50\% yaitu $2.56 \mathrm{MPa}$. Hal tersebut dikarenakan komposisi yang sama dan sesuai antaran kitosan-PVA. 
2. kekuatan modulus young yang sangat tinggi yaitu sebesar 9,84 $\mathrm{MPa}$ pada perbandingan kitosan-PVA 50\%-50\%, hal tersebut disebabkan membran memiliki komposisi yang sama atau sesuai antara kitosan dengan PVA sehingga membran memiliki ukuran pori yang rapat, teratur, dan saling berdekatan serta proses pengeringan yang cepat sehingga membran menjadi sangat kuat

\section{SARAN}

Saran yang dapat direkomendasikan dari penelitian ini adalah:

1. Perlu adanya penelitian lanjutan dari membran komposit kitosan-PVA dengan penambahan unsur lain

2. Perlu adanya alternatif lain untuk membuat membran sebagai pembanding membran kompisit kitosan-PVA

3. Parlu adanya penelitian lanjutan tentang pembuat Membran komposit kitosan-PVA.

4. Perlu adanya perubahan bahan dasar lain untuk pembuatan kitosan.

\section{DAFTAR PUSTAKA}

Apsari, Ajeng Tanindya, dkk. 2010. Studi kinematika penyerapan ion chorium dan ion tembaga menggunakan kitosan produk dari cangkang kepiting. Skripsi. Semarang: UNDIP.

Aryanto Wiwit, dkk. 2012. Pembuatan membran komposit kitosan/vanili/polivinly alkokol/lempung sebagai membran polimer elektrolit. Skripsi. Surakarta : USMS.

Fahra F. Indah, dkk (2012). Pengaruh Pva Terhadap Morfologi dan Kinerja Membran Kitosan dalam Pemisahan Pewarna Rhodamin-B. Prosiding Seminar Nasional Kimia Unesa 2012 - ISBN : 978-979-028-550-7.

Harniangsih, 2010. Pemanfaatan Limbah Cangkang Kepiting menjadi Kitosan sebagai Bahan pelapis pada Buah Stoberi. Jurnal Teknik Kimia No. 1 2010, Hal: 7-12.

Meriatna. 2008. Penggunaan Membran Kitosan untuk Menurunkan Kadar Logam Krom(Cr) dan Nikel(Ni) dalam Limbah Cair Industri Pelapisan Logam. Tesis. Fakultas Teknik Kimia, Universitas Sumatera Utara.

Mulder, M. 1991. Basic Principles of Membran Technology. Netherlands: Khewer Academic Publisher.

Rahayu, L. H, dkk. 2007. Optimasi Pembuatan Kitosan dari Kitin Limbah Cangkang Rajungan (Prontunus pelagicus)untuk Adsorben Ion Logam Merkuri. Jurnal Reaktor, Vol. 11 No. 1, Juni 2007, Hal: 45-49.

Sanjaya, Indah, dkk. 2007. Adsorpsi Pb (II) oleh Kitosan Hasil Isolasi Kitin Cangkang Kepiting Bakau (Scilla). Jurnal Ilmu Dasar Vol. 8 No. 12007 :30-36.

Setiawan, Dian Aris, dkk. 2015. Pengaruh Konsentrasi dan Preparasi Membran Terhadap Karakterisasi Membran Kitosan. Jurnal Keteknikan pertanian tropis dan Biosistem. Vol. 3 No. 1, Februari 2015, 95-99.

Saputra, Bobi Wahyu. 2008. Desain Sistem Adsorpsi. Jakarta: UI.

Trisnawati Elin, dkk. 2013. Pembuatan Kitosan dari Cangkang Kepiting sebagai Pengawet Buah Duku dengan Variasi Lama Pengawetan. Jurnal Teknik Kimia No. 2, Vol. 19, April 2013

Umeda, M. 1956. Experimental Study Of Xanthene Dyes As Carcinogenic Agents. Gann 47-51.

Wardaniati, Ratna Adi, dkk. 2008. Pembuatan Kitosan dari Kulit Udang dan Aplikasinya sebagai Pengawet Bakso. Jurnal. UNDIP.

Wahyudi Tatang, d kk.2010. Pembuatan Serat Nano Menggunakan Metode Electrospinning. Skripsi. Arena Tekstil Volume 26 No.1 - Juni 2011 : 1-60

Wibowo, S. (2006). Produksi kitin kitosan secara komersial. Prosiding seminar nasional KitinKitosan. DTHP, Institut Pertanian Bogor.

Zulfikar. M. Ali., Wahyuningrum.D., Berghuis, Tanyela Berghuis. 2009.Pengaruh Konsentrasi Kitosan Terhadap Sifat Membran Komposit Kitosan-Silika untuk Sel Bahan Bakar. Prosiding Seminar Kimia Bersama UKM-ITB VIII. Hal 254- 262. 